九州大学学術情報リポジトリ

Kyushu University Institutional Repository

\title{
The Later Development of A Solenogastre, Epimenia Verrucosa (Nierstrasz)
}

Baba, Kikutaro

The Amakusa Marine Biological Laboratory, Tomioka, Kumamoto-ken.

https://doi.org/10.5109/22588

出版情報 : 九州大学大学院農学研究院紀要. 6(1)，pp.21-40，1938-05. Kyushu Imperial University バージョン：

権利関係 : 


\title{
THE LATER DEVELOPMENT OF A SOLENO- GASTRE, EPIMENIA VERRUCOSA $(\text { NIERSTRAS } Z)^{1)}$
}

\author{
Kikutarô BABA
}

For a number of years past the writer has been engaged in the study of a solenogastre, Epimenia vermeosa (NIERSTRASZ), from Amakusa, Japan, the results of which will appear later in a series of systematic and morphological papers. In the present article it is intended to give account of the embryology of the afore-said animal, special stress being laid on the external and internal features of the development through the trochophore until it assumes the adult form after metamorphosis. Owing to lack of observations on the cell lineage and gastrulation the work remains incomplete. Yet I think it may throw some light upon the phylogeny of the solenogastres, more especially with regard to the relationship between this group and the chitons.

The work has been carried out in the Amakusa Marine Biological Laboratory under the direction of Prof. H. Orshima, to whom I would express my gratitude for the facilitics afforded me.

The pioneer studies on the development of the solenogastres were made by Pruvot (1890, '92) on Nematomenia banyulensis ${ }^{2}$ ) (Lepidomeniidae) and Rhopalomenia aglaopheniae ${ }^{31}$ (Proneomeniidae), and by Hzath (1918) on Halomenia gravida (Neomeniidae). PRUvot succeeded in bringing eggs to trochophores and finally to metamorphosis, and described briefly the general features of the successive stages. One of the most interesting facts he found was that the larva of Nematomenia possesses 7 imbricating shell-like plates.

1) Contributions from the Zoolugical Laboratory, Kycisyu Imperial University, No. 115. Papers from the Amakusa Marine Biological Laboratory, No. 67.

2) Syn.: Dondersia banyulensis.

3) Syn.: Proneomenia aglaopheniac. 
HEATH's work, though greatly in detail, was exclusively concerned with the study of serial sections of developing eggs in the cloacal

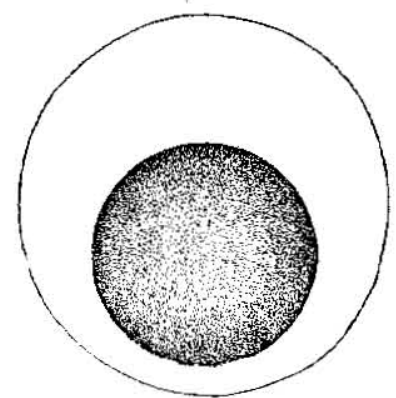

Fig. 1.--Unsegmented egg

Diam. 0.4 min: chamber of a parent animal, the general appearance of the larva being left unkown.

The animal, Epimenia vernicos ${ }^{13}$, was taken in fair numbers by a fishing net in the vicinity of the Laboratory from the depth of about 40-60 metres. It may well be kept alive for several days in the aquarium without any special equipment, but it was very difficult indeed to find the animal in the act of egg-laying, the observations made by me along this line being few in number.

It was in the morning of June 13th, 1936, that a considerable number of eggs were first seen developing into trochophores in an aquarium (sea-water temperature about $23-24^{\circ} \mathrm{C}$ ) in which two mature individuals (length about $30 \mathrm{~cm}$ ) had been kept for one day. The oviposition presumably had taken place during the night.

The eggs (Fig. 1) which failed to segment were perfectly spherical, about $0.4 \mathrm{~mm}$ in diameter ${ }^{2}$, and uniformly packed with orange-yellow yolk granules. The trochophores themselves were reared through metamorphosis up to the larvae which assumed the external characters of the adult.

Next year on September 1st, at about $80^{\prime} \mathrm{clock}$ in the evening, I had a chance of getting some 40 eggs which had just been freed from a mature specimen about $27 \mathrm{~cm}$ in length. The temperature of the sea-water at that time was $27^{\circ} \mathrm{C}$. The eggs were small, about $0.27 \mathrm{~mm}$ in diameter, and of a light yellowish gray colour. They continued development to become blastulae, and then all diẹd.

One thing which could be seen in both cases was that the eggs, cach enclosed within a roomy capsule, are not laid singly. but in an ill-defined mucous band of exceedingly viscid consistency.

1) Syn.: Dinomenia verrecose (Nitkstfas\% 1992. pp. 11-18) This is subsequently

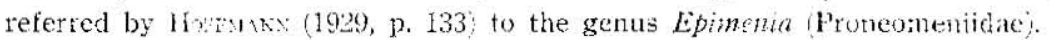

2) The eggs measure $0.11-0.12 \mathrm{~mm}$ in Nimatonenia, $0.26 \mathrm{~mm}$ in Rhopalomenin, and $0.32 \mathrm{~mm}$ in Halomenia. 


\section{GENERAL SKETCH OF DEVELOPMENT}

Early cleavages: In the beginning of the discussion a few words may be expended concerning the earliest life history of Epimenit vermosit. The first cleavage of the egg takes place about 50 minutes after oviposition. The two cells resulting from this division are usually cqual in size, but in some cases they are apparently unequal, the one being larger than the other. In about an hour the egg divides into 4 , and again in about half an hour into 8 cells. In this last-named stage, the upper half is seen to consist of 4 cells decidedly smaller than the lower sisters. During the successive stages of development the cells proliferate rapidly, and about $B$ hours after the 8 -cell stage the egg itself is converted into an advanced blastula.

Trochophore (Fig. 2; 1'l. 1, figs. 1-2): This stage is reached within one day from egg-laying. The youngest trochophores which I have scen measured $0.6-0.65 \mathrm{~mm}$ in length and $0.3 \mathrm{~mm}$ in diameter. The body is short and cylindrical, thicker in front than behind, and is divided superficially into 3 segments, viz., cephalic, middle and caudal. The middle segment is the largest and constitutes the trunk. On the ventral side in the middle line there runs a longitudinal ciliated furrow representing the so-called foot (Pl. 1, fig, $\mathrm{ib}, \mathrm{h}$ ). This organ is continued in front into the prepedal cavity (Flimmerhöhle) with strong cilia. The stomodeal invagination ( $\mathrm{Pl} . \mathrm{i}$, fig. $1 \mathrm{~b}, \mathrm{i}$ ) is visible as a small pit immediately in front of the prepedal cavity. The integument of the trunk is not ciliated but is covered with a thick cuticle secreted by the underlying hypodermis. Some of the hypodermal cells develop as large pear-shaped papillae which show themselves as rounded tubercles on the integumental surface. There are spindle-shaped shiny spicules in the integument. The cephalic segment is dome-shaped with a tuft of apical flagella in the centre of the dome. At this region the cuticle is thin but the whole surface becomes covered by short cilia. In some specimens the papillae similar to those of the trunk are also distributed here and there on the dome. The cephalic segment can easily be withdrawn into the trunk and the point of invagination, or better the border of the two segments, is marked by an encircling groove. Abutting on this groove and just at the anterior cdge of the trunk is a band of long cilia. This ciliary band is called here the prototroch (Pl. 1, fig. $1 \mathrm{~b}, \mathrm{c}$ ). The 
caudal segment has also the shape of a dome covered with short cilia and is marked off from the trunk by an encircling groove. The ciliary band which the caudal segment possesses may be termed the telotroch (II. 1, fig. $1 \mathrm{~b}, \mathrm{~g}$ ). The caudal segment can be withdrawn into the trunk, just as in the case of the cephalic segment.

Internally the trochophore has a large yolky mass of endoderm (Fig. 2, g), and the space between it and the ectoderm (integument) becomes gradually filled with proliferating mesoderm cells (Fig. 2, e). The stomodaeum (Fig. 2, i) extends inward as a blind canal reaching the anterior end of the endodermal mass. The rudiment of

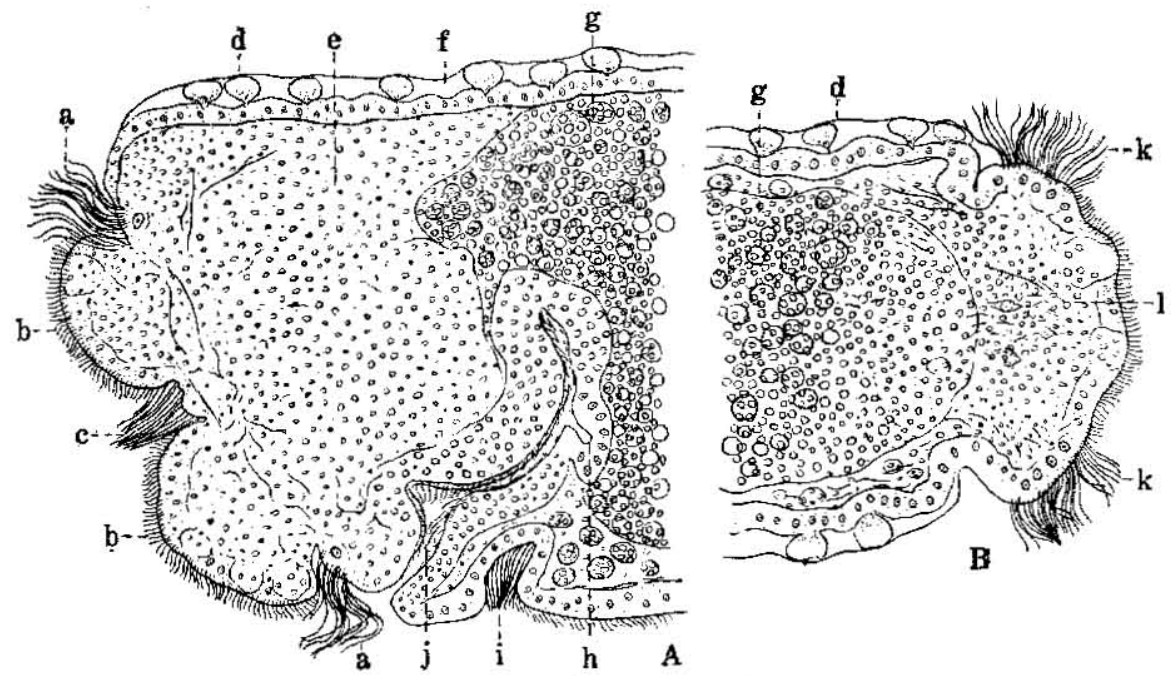

Fig. 2.- Median longitudinal sections of young trochophore $(\times 300)$, cut through anterior (A) and posterior (B) end of body. a prototroch, b. cephalic segment, c. apical flagella, d. middle segment, e. mesoderm, f. ectoderm, g. endodermal mass. h. rudiment of fore-gut, i. prepedal casity, j. stomodaeum, k. telotroch, 1. caudal segment.

the fore.gut (Fig. 2, h) first appears at the posterior wall of the stomodaeum. The nerve cells and fibres are more or less concentrated to form a pair of cercbral ganglia at the anterior dorsal side of the stomodaeum. The prepedal cavity and foot have on each side a continuous stripe of mucous glands (pedal glands).

The whole body of the trochophore is vivid orange-yellow with the papillae opaque white. For a while within the egg-capsule the worm is seen making a rapid rotatory movement, but it soon 
commences to make its way through the capsule and swims out in the open sea-water.

As the development proceeds, the body of the trochophore becomes elongated and the foot narrowed ( $\mathrm{Pl}$. 1, figs. $2 \mathrm{a}-2 \mathrm{~b}$ ). The length of body increases up to $0.75-0.8 \mathrm{~mm}$. The lateral and pedal nerve cords now arise from the cerebral ganglia.

Metamorphosis: The trochophores lead their free-swimming life for only one day. After this they settle on the base of the vessel in which they are kept and undergo very speedy metamorphosis. During this process transformation takes place almost altogether on the cephalic and caudal scgments: the apical flagella and ciliary bands disappear,- the head and tail become covered by the non-ciliated integument similar to that of the trunk.

Two-day larva (Fig. 3; PI. 1, fig. 3): The larva thus metamorphosed now assumes the general appearance of the adult. The body is vermiform with the head larger than the tail. It measures

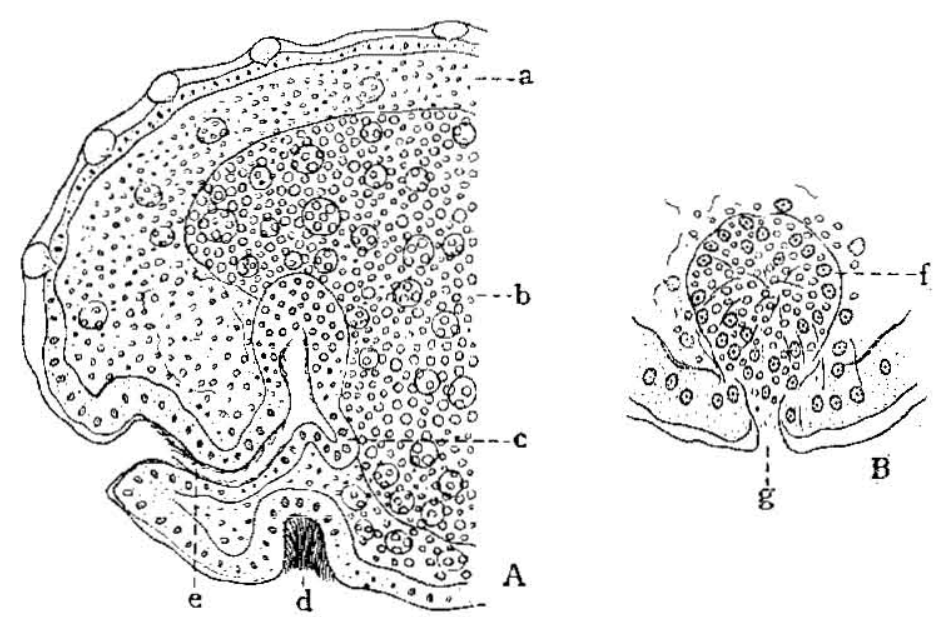

Fig. 3.--Young larva (2 days) immediately after metamorphosis. A. Median longitudinal section cut through anterior end of body ( $K 350)$. a. meso. derm, b. endodermal mass, c. rudiment of fore-gut, d. prepedal cavity, e. stomodacum. 13. Transverse section cut through proctodeal invagination (g). f. ructiment of cloaca $(\times 500)$,

about $0.8-0.9 \mathrm{~mm}$ in length. The larva is very inactive. If disturbed or irritated it will sometimes bend the body either to the right or left or ventrally at some angle to the trunk. Closely behind the pedal furrow is visible a small pit which is the opening of 
the proctodaeum ( $\mathrm{Pl} .1$, fig. 3, d). The proctodaeum is invaginated inward to form a short blind sac (Fig. 3, B, f) reaching the posterior end of the endodermal mass.

Eight-day larva (Pl. 1, fig. 4): Further growth of the larval body is only gradual. Eight days after the larva has commenced development its body-form becomes more elongated than before and the integument colourless and transparent. The endodermal mass alone continues to hold the original colour of the egg. The length of the body at this stage measures about $2 \mathrm{~mm}$. The stomodaeum is clearly differentiated into atrium and fore-gut.

Sixteen-day larva (Fig. 4 ; Pl. 1, fig. 5): About 8 days later when the larva has grown to a length of $2.5 \mathrm{~mm}$ there appear in the interior of the body the first formations of a heart, gonoducts and salivary glands. The heart (Fig. 11, a) arises as a mass of

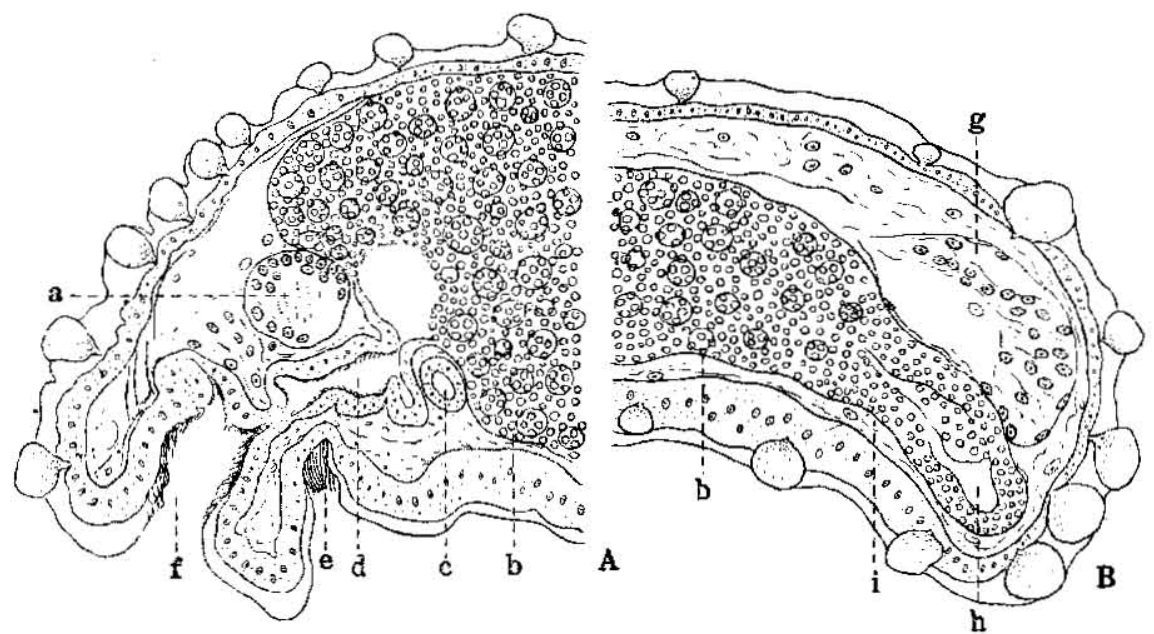

Fig. 4.-Median longitudinal sections of 16 -day Iarva $(\times 350)$, cut through cephalic (A) and caudal (B) end of body. a, cerebral ganglion, b. endodermal mass, c. rudiment of salivary gland, d. fore-gut, e. prepedal cavity, f. atrium, g. pericardium with a rudiment of heart, $h$. rudiment of cloaca, $i$. rectal portion of endodermal mass.

diaphanous cells hanging down from the dorsal wall of the pericardium. This latter organ (Fig. 4, g; 11, f) is a thin-walled roomy sac continuous with the dorsal sinus in front. It is situated dorsally on the posterior end of the endodermal mass. The salivary glands (Fig. 4, c) are a pair of short diverticula extending from the lateral walls of the fore-gut. The inward 
extension of the proctodaeum forms the rudiment of a cloaca which, in turn, gives rise to a pair of gonoducts (Fig. 11, e). The endodermal mass remains solid and undifferentiated, but it now takes the form of a well-defined mass extending from behind the fore-gut to the anterior edge of the cloaca. It is more or less large in front, but gradually decreasing in size as it runs backwards. The endodermal mass is destined to bccome the mid-gut and the rectum following it. The greater part of the mesodermal cells in the space between integument and digestive organs are converted to form a loose framework of connective tissue.

Thirty-day larva: We now proceed to the study of the larvae which have survived about 2 weeks since tho preceding stage. The general appearance is much as before but the integumental papillae show a tendency to become less and less marked. The length of body measures $2.8-3.0 \mathrm{~mm}$. The mid gut including the rectal portion acquires a lumen and the cndodermal cells are differentiated to form a lining epithelium of a single layer. The mid.gut is in close connection with the fore-gut and cloaca but no internal communications as yet take place among them. The salivary glands extend backwards to a considerable extent. They are destined to become a duct and its continuation, namely a g!andular portion. The dorsal sinus and pedal sinus (ventral sinus) run along almost the whole length of the mid-gut.

The larvae continued their development in the laboratory for a month. After that they became sluggish, presumably owing to the exhaustion of the nutritive yolk they contained.

\section{HISTOGENY AND ORGANOGENY}

\section{Integument (Fig. 5)}

The trunk integument of the trochophore is covered by a cuticle (Fig. 5, a) which is thickest towards the dorso-lateral region and becomes thinner towards the ventral side. The hypodermis is single-layered (Fig. 5, b). It has an underlying basement membrane. The papillae (Fig. 5, e) are pear-shaped, consisting of a bulbous cap and a small stalk. The cap is unicellular with a distinct nucleus situated at the proximal end of the cell. The cap-cell becomes highly vacuolated by fixatives. In the fresh state it has 
much the appearance of a mucous cell but shows no affinity to specific mucus stains. The stalk of the papilla is formed of a syncytium which has a number of nuclei near the distal end of
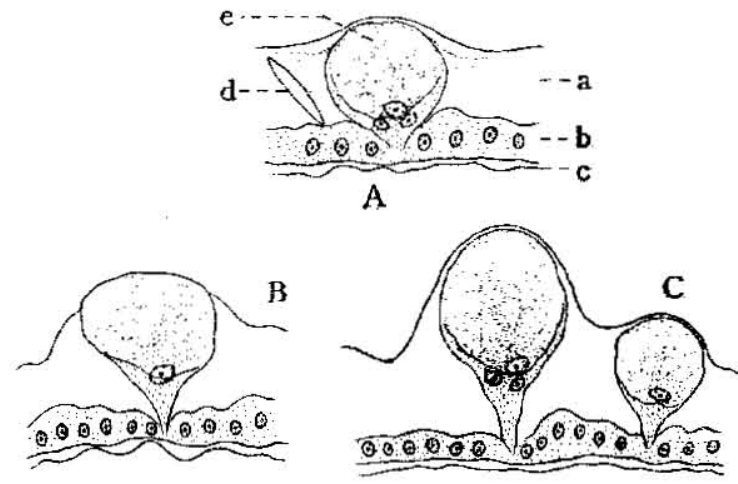

Fig. 5.-Development of integumental papillae $(\times 600 \% \mathrm{~A}$. Young trochophore, B. 16-day larva, C. 30-day larva. a. cuticle, b. hypotermis, c. basement membrane, d. spicule, e. papilla.

the stalk. Over the papillae the cuticle is elevated in a thin covering. The spicules (Fig. 5, d) are embedded in various ways in the integumental cuticle. They do not differ much in shape from the spicules of the adult. One may recall here for $\mathrm{com}$. parison that in Nematomenia and Rhopalomenia the larval spicules are large and imbricating and in the latter genus they are known to have the fate of being rejected finally to give way to adult spicules (Pruvot 1892, p. 1212). With continued growth of the body the papillae become elongated especially at the stalk portion and the cuticle thickened contrary to the low hypodermis (Fig. 5, B-C).

Foot and Prepedal Cavity (Figs. 6-7)

The foot with its pedal glands arises as a narrow longitudinal depression on the ventral surface of the trochophore. At first it is only slightly arcuated ventrally (Fig. $6 \mathrm{~A}, \mathrm{~d}$ ), but later the arcuation becomes more and more marked (Fig. 6, B-C), the organ growing to a ridge-like formation in the larva of about 30 days old". Thus it may be inferred that the foot of Epimenia is in

1) In the adult form the foot, while remaining small relative to the size of the body, is much complicated, having $3-5$ longitudinal folds on the surface. 
progressive development from a simple type, with no indication as to its being derived from a highly organized foot such as is found existing in the chitons (cf. HeATH 1899, pp.630-631). The lining
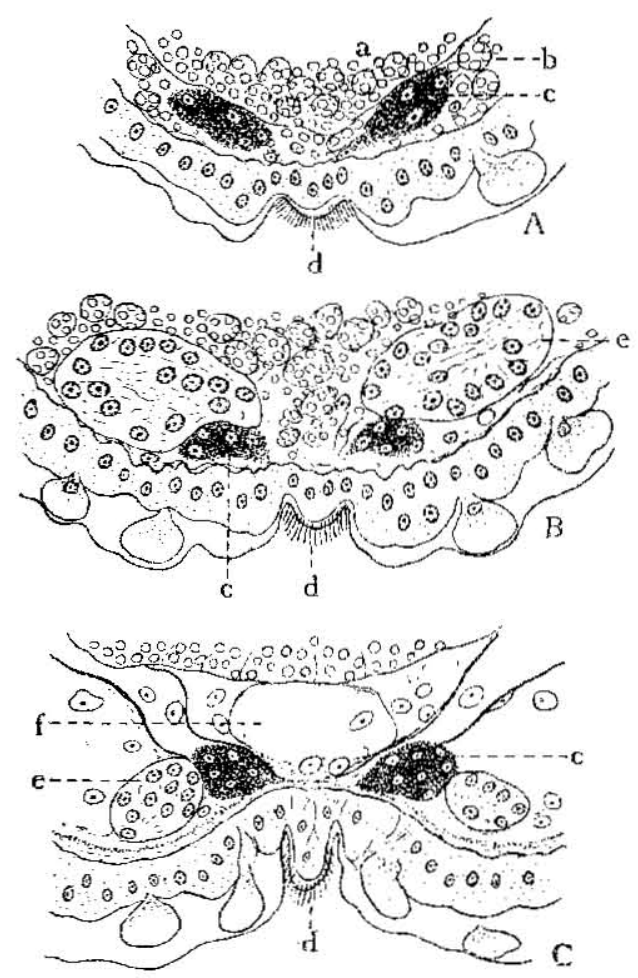

Fig. 6.-Development of foot as shown by transverse sections $(<500)$. A. Young trochophore, B. advanced trochophore, C. 30-day larva. a. endodermal mass, b. mesoderm, c. pedal gland, d. foot, e. pedal ganglion, f. pedal sinus.

epithelium of the foot is made up of high columnar cells with a thin cuticle and short cilia on the free surface.

The prepedal cavity (Fig. 2, i) first appears also on the ventral surface of the trochophore as a shallow but spacious invagination in direct connection with the foremost end of the foot. The lining epithelium at this region roughly resembles that of the foot but has much stronger cilia and pedal glands. The invagination 
becomes deeper with age (Fig. 7), and this is aided largely by an

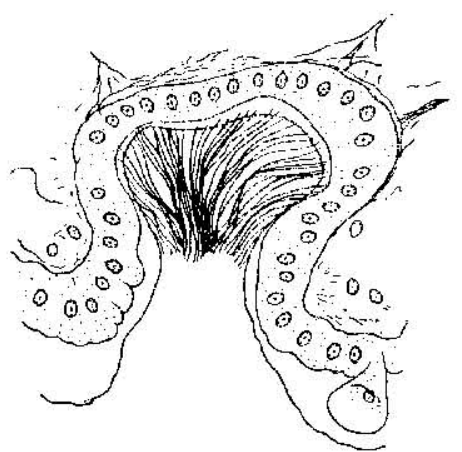

Fig. 7--Transverse section of prepedal cavity in 30-day larva $(\times 500)$.

inward extension of the integument which borders upon the epithelium of the prepedal cavity.

\section{Stomodaeum}

In the young trochophore the stomodaeum (Fig. 2, j) is represented by a short blind canal extending backwards from the stomodeal pit to the fore end of the endodermal mass. The wall is formed of large undifferentiated cells packed with yolk granules and bearing a thin cuticle and short cilia on the free surface. From the posterior wall of the stomodaeum is given off a small saccular organ (Fig. 2, h) which has a columnar epithelium with distinct basal nuclei and is clearly marked off from the proper stomodacum by lacking yolk granules. Much the same conditions are found in the youngest larva immediately after metamorphosis (Fig. 3, c). But in the course of further development the stomodaeum with its wall is differentiated into a spacious cavity, now called the atrium (Fig. 4, f). The saccular organ develops to form a large foregut (Fig, 4, d) and comes to open towards the mid-gut at a stage corresponding to the 16-day larva. About this time the first indication of salivary glands (Fig. 4, c) appears on the posterior lateral walls of the fore-gut, consisting of a low epithelium without a cuticle and cilia. Though short at first, these glands increase gradually in extent and in the 30-day larva 
they may be seen as a pair of simple longish tubes ${ }^{i)}$ running on the ventral side of the mid-gut.

\section{Proctodaeum}

The proctodaeum breaks through at a later period than the stomodaeum, thus presenting itself first in the larva which has just undergone metamorphosis. The blind portion of the proctodaeum forms a swollen sac closely applied to the posterior end of the endodermal mass. The sac is the rudiment of a cloaca (Fig. 3, f). It is lined by a tall columnar epithelium with yolk granules. In about the 16-day stage there arise on the neck of the proctodaeum a pair of short diverticula which may develop into gonoducts (Fig. 11, e). Soon afterwards the cloaca aquires a moderately spacious lumen and the lining epithelium becomes covered by long cilia.

\section{Endodermal Mass}

As already stated the endodermal mass is destined to differentiate into a mid-gut and the rectum following it. At first this mass is usually solid, consisting of various-sized spherical cells packed with yolk granules. Later, at about the stage corresponding to the 30-day larva there develops in the interior of the endodermal mass or the mid-gut a spacious lumen ${ }^{2)}$ possibly as a result of absorption of the yolky cells as nutritive. Then the wall of the mid.gut is reduced to a single-layered epithelium which is thickest towards the lateral and ventral sides and becoming thinner dorsally (Fig. 12, f). The rectal portion does not differ much in structure from the mid-gut except that it is smaller in size and that its epithelium is approximately of equal thickness.

\section{Nervous System (Figs. 8-9)}

The nervous system is as usual ectodermal in origin. During the earliest stage of trochophore, cells may be seen proliferating

1) In the adult form this becomes differentiated into two parts: a glandular portion and its duct. Niritrasz (19)2, p. 16) distinguished the duct as 'tubular ventral appendage of the pharynx', but quite obviously this appellation is not to be recommended.

2) The first indication of such a lumen may sometimes be found in earlier stages. 
inward from the ectoderm of the cephalic segment in the two slight depressions which lie laterally and in front of the stomodeal pit (Fig. 8A, a ; 8B). These cells migrate gradually towards the dorso-lateral regions of the stomodaeum, and develop there in a pair of concentrated cerebral ganglia connected by a fairly long commissure (Fig. 9, A). Soon there appear on either side two wellmarked ganglia from cach half of the ccrebral ganglia, one situated laterally and the other ventrally (Fig. 9, B). The lateral ganglion is much smaller than the ventral one. Both extend a short way backwards. They decrease in size from front to rear. As development
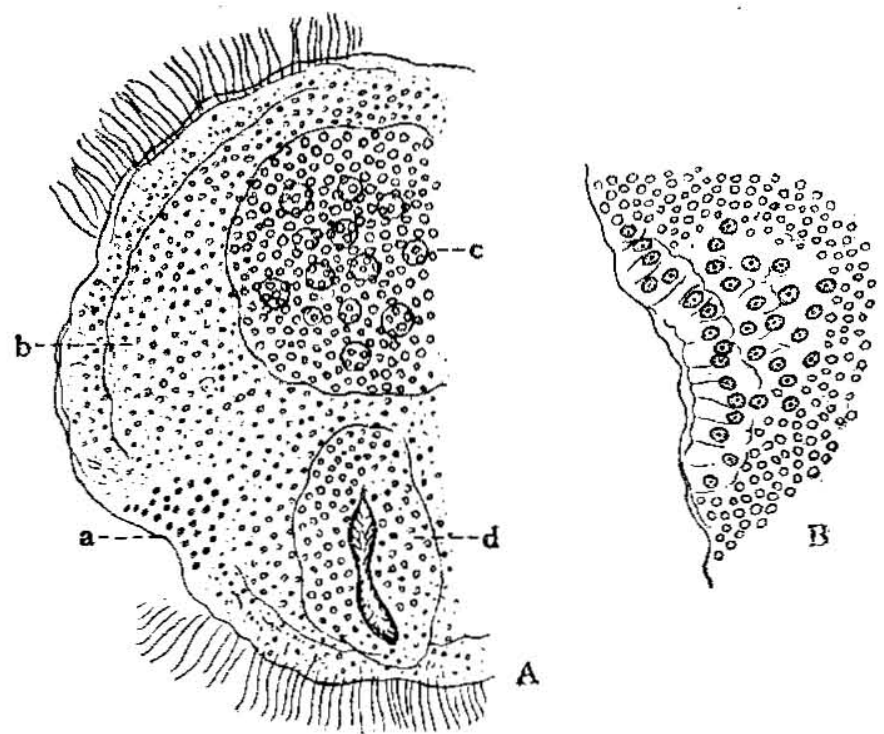

Fig. 8.-Transverse sections of young trochophore, cut through cephalic segment. They show the origin of nerve cells from the depression marked by a. The same spot is strongly enlarged in the fig. B. b. mesoderm, c. endodermal mass, d. stomodaeum. Scale in A. $\times$ 200 ; in $\mathrm{B}, \times 500$.

proceeds,- the two cerebral ganglia come close together (Fig. 9, C). The lateral and ventral ganglia reach the proctodeal region (Fig. 11, c-d), thus turning into four longitudinal nerve cords interlinked transversally by interpedal commissures and latero-pedal connectives. Such an advanced organization can first be met with in the larva of about 16 days old. 


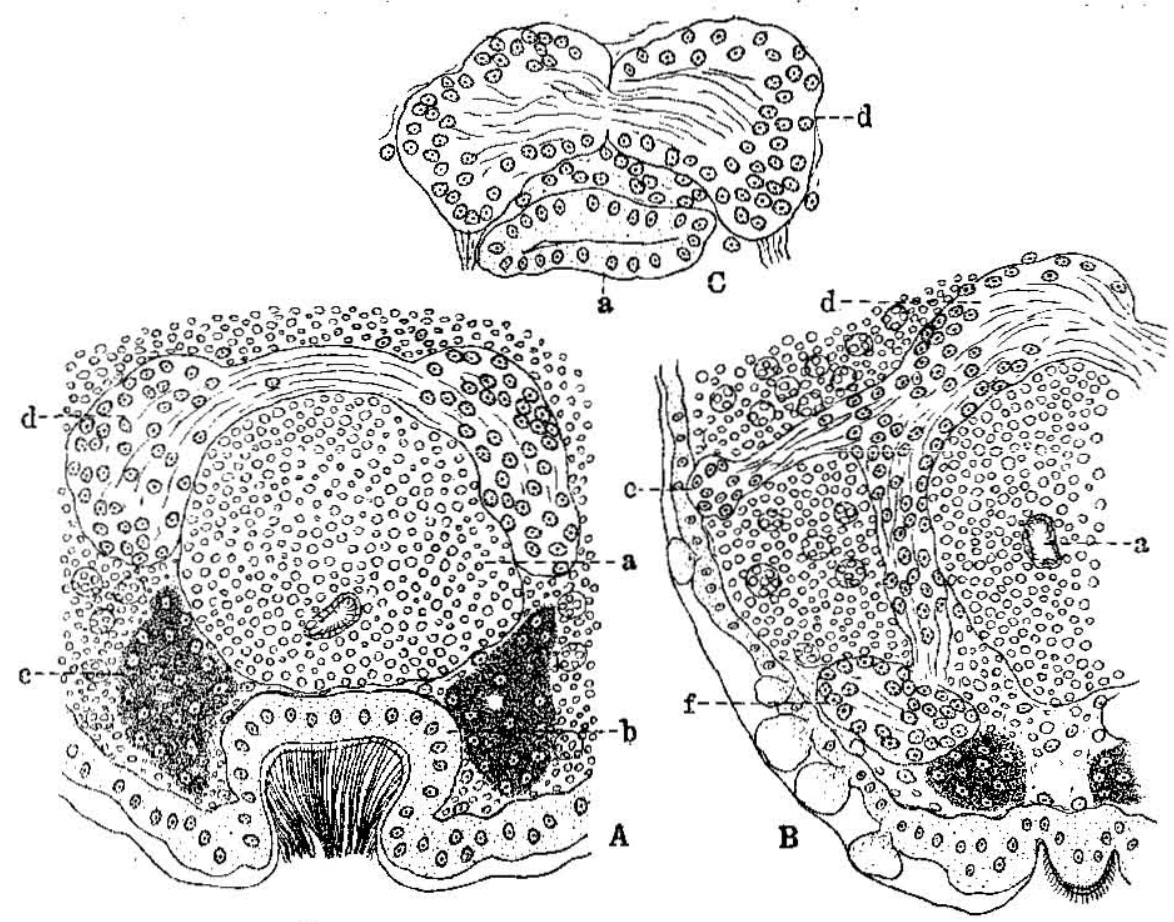

Fig. 9.-Development of nervous system as shown by transverse sections $(\times 500)$. A. Young trochophore, B. slightly advanced trochophore, C. 8-day larva. a. stomodaeum, b. prepedal cavity, c. pedal gland, d. cerebral ganglion, e. lateral ganglion (nerve cord), f. pedal ganglion (nerve cord).

\section{Mesoderm (Fig. 10)}

The mesoderm of the youngest trochophore is found filling up the space between the integument and endodermal mass (Fig. 10). These latter are at first touching at the dorsal side but later come to be interlined by the sheets of mesoderm which extend upwards. The individual cells forming the mesoderm are spherical and yolkladen, and have much the appearance of the endodermal elements. At about 16-day stage there takes place a well-marked differentiation in the part of the mesoderm. The result is first of all the formation of a loose connective tissue framework, but the hypodermal (Fig. 12, d) and the transversal (Fig. 12, b) muscle fibres are equally developed from the mesodermal cells. Regarding the hypodermal muscle fibres they are so arranged as to form an 
inner longitudinal and an outer circular muscle layer. The trans.

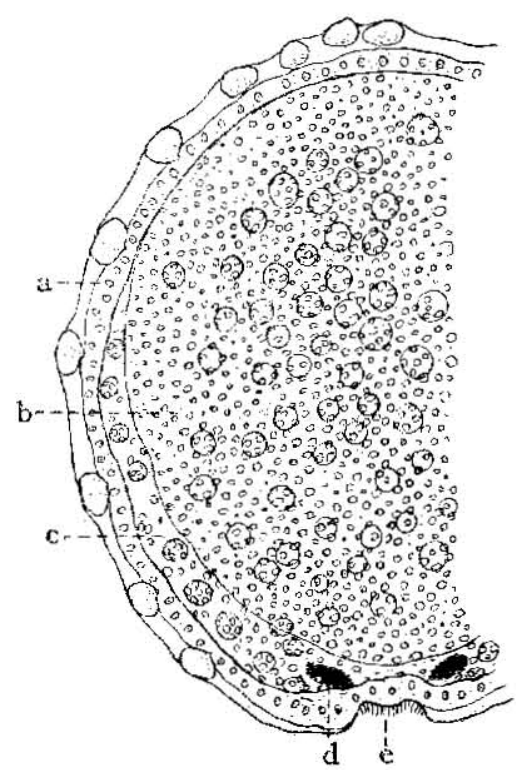

Fig. 10. - Transverse section of young trochophore, left hali $(\times 350)$. a. ectoderm, b. endoderm, c. mesoderm, d. pedal gland, e. foot.

versal muscle fibres arise from above the foot and run obliquely to the lateral walls of the body.

Circulatory System (Figs. 11-12)

The circulatory organs arise possibly from the mesodermal cells on the dorsal side of the rectum at a stage roughly corresponding to the 16.day lacra (Fig. 4, g). A mass of diaphanous cells with large nuclei arc at this time plainly visible hanging ventrally from the dorsal wall of the pericardium, and forming a simple saccular organ (Fig. 11, a). This is the rudiment of a heart ${ }^{1)}$, which has a small lumen towards the dorsal side of the organ. The pericardium (Fig. 11,f) is a thin-walled roomy sac directly continued in front into the dorsal sinus ${ }^{2)}$ (Fig. 12, g).

1, 2) In the adult form, the heart consists of a ventricle and a pair of auricles. The ventricle passes forwards into the dorsal sinus. This latter is held between the paircd tubular gonads contueted posteriorly with the pericardial chamber. N nation of the dorsal wall of the pericardium. 


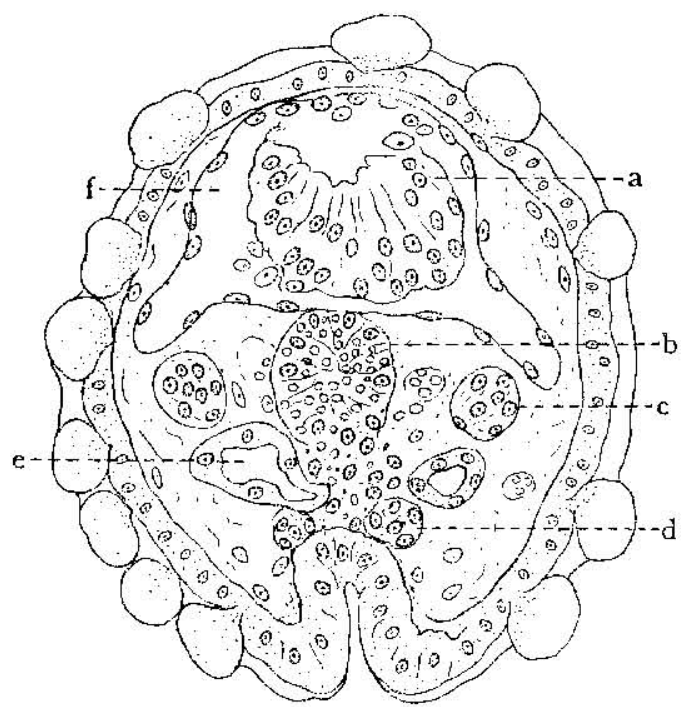

Fig. 11.-Transverse section, cut through proctodeal pit of latva 16 days old $(x 500)$. It shows the development of a heart (a) within the pericardium (f) b. rudiment of cloaca, c. lateral nerve cord, d. pedal nerve cord, e. rudiment of gonoduct.

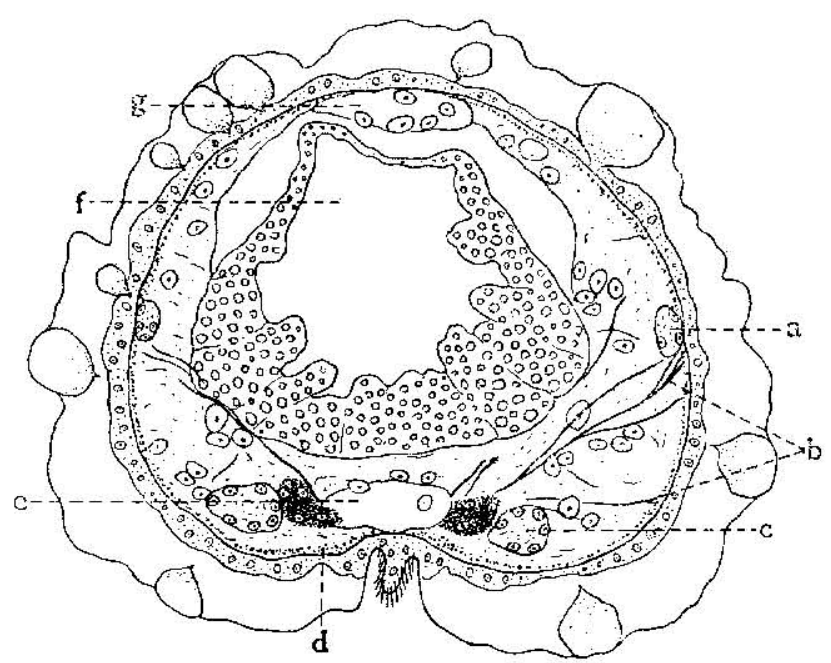

Fig. 12.-Transwerse section of 3J-day larva, cut through mid-gut region ( 359 ). a. lateral nerve cord, b. transversal muscles, c. pedal nerve cord, d. hypodermal muscles, e. pedal sinus, $f$. mid-gut, g. dorsal sinus. 
This latter extends forwards along the whole length of the midgut immediately below the mid-dorsal integument. In addition there is a ventral sinus (Fig. 12, e) which passes equally along the length of the mid-gut, but just above the pedal furrow. The dorsal sinus is a little larger than the ventral one. Both are welldefined by a delicate membrane of much the same appearance as the pericardial wall.

\section{GENERAL CONSIDERATIONS AND CONCLUSIONS}

Comparing now the development of Epimenic with that of other solenogastres (Halomenia, in particular Nematomenia and Rhopalomeniat ${ }^{1)}$, there is a difficulty in finding fundamental resemblances throughout, except in the process of earliest cleavages wherein the egg is divided first into two halves of equal or unequal sizes and then into one large and three smaller blastomeres.

The Epimenia trochophore is externally three-segmentcd as in the case of Nematomenia, but this resemblance appears to be only superficial. Thus in Nematomenia the ciliary band is confined to the posterior end of the middle segment, the middle and caudal segments constitute the so-called test, and under cover of this organ is developed a caudal bud. Only the cephalic segment which bears apical fagella is alike in the two genera.

As to the transformation of the trochophore into larval form, there exists not a little difference between Epimenia and Nematomenia. In the latter genus the test is cast off at the moment of metamorphosis. The caudal bud elongates to form a trunk which is covered mid.dorsally by seven shell-like plates and laterally by large larval spicules. Obviously such are not the case in Epinenia.

In the origin of the nervous system and prepedal cavity Halomenia roughly agrees with Epimenia. But it has some distinguishable characteristics, namely, a test is formed to enclose partially the larval body. The mid-gut is found in the very carly stage communicating with the stomodaeum. The terminal ring of Halomenia recalls to a certain extent the caudal bud (of Nemato-

It is said that the developmental process of Rhopalomenit is nearly the same ats that of Nimatomenia. So in the following discussions matters on Rhopalomenia may sometimes be represented by Nematomenia. 
menia) and telotroch (of Epimenia), but an exact homology among them is yet open to doubt.

It is generally believed that the solenogastres are an extremely primitive, and at the same time, a degenerated group of molluscan animals which have derived from such highly organized forms as chitons. In 1921 ODHNER proposed a serious objection to this, claiming that as a whole the solenogastre organizations are in progressive-not retrogressive-development in various directions from lower types to complicated structures as those existing, for example, in proneomenias. Many of his arguments in this connection are suggestive and also deserve to be maintaincd. But he, as Thirs: and some others have already done, tried to exclude the solenogastres from the molluscan phylum on the ground that these animals have no differentiated foot nor mantle cavity, and went too far in seeking the closest affinities of the solenogastres among the lower type of animals like Scolecida (cf. ODHNI:R 1921, pp. 54-79).

No one will oppose the claim that both Mollusca and Annelicla have originated from a common ancestor represented by the trochophore, these two groups exhibiting wonderfully precise and deep-seated resemblances throughout their carly developmental stages. In one point however the molluscan trochophore differs from that of Annelida; that is the absence of nephridial organs (archinephridia and protonephridia). Basing my observation on Epimenia trochophore which has no such organs, the solenogastres might safely be considered as belonging to the phylum Mollusca. Furthermore this line of reasoning is corroborated by the fact that the animals in question possess a mantle, a foot and a radula", all of which are essentially important molluscan characteristics.

Appearance may suggest close relationship between solenogastres and chitons, but we must not evaluate it too highly. So far as my observation goes, the Epimeniu foot, allhough representing that of the Mollusca in general, shows no evidence that it is reduced directly from the expanded foot sole of the chiton. As already pointed out by ODHNer (1921, pp. 59, 62) the two types, solenogastres and chitons, differ from each other in the

I) The foot is absent in the Chaetodermatidae. Also there are a number of genera in which no radula is found. 
organization of the nervous system especially with regard to the arrangement of pedal nerve cords which, while running parallel in the former type far remote outside the pedal furrow, in the latter are included within the limit of a pedal disk. Here I wish to call attention to the fact that in their origin the lateral and pedal nerve cords do not arise as such but in well-marked ganglia from the concentrated cerebral ganglia. As for the shellplates which are of highest importance for the characterization of the chitons, they were proved to be wanting altogether in Efrimenia larva ${ }^{1)}$. This observation is apparently inconsistent with the prevailing view that the solenogastres have descended from some chiton-like form by means of a reduction of shell-plates. Furthermore, when we take into consideration the general development from trochophore to larval stage, it invariably follows that as between Epimenia and the chitons the differences are more remarkable and significant than are the resemblances. Yet I reckon the chitons, among the five molluscan classes, to be the nearest relatives of the solenogastres only because these two types exhibit an approximate similarity in the early process of cleavages (cf. НЕАTH 1899 , pp. 578-579).

1) As alteady cited elsewhere Prevot (1890, p. E92) observed 7 shell-like plates as existing in the mid-dorsal region of the Nematomenia larva, but thus far the question whether these structures are really the homologues of the chiton shellplates has not been satisfactorily answered. 


\section{LITERATURE}

Hइsm, H. 1899 The development of lschachiton. Zool. Jahrb., Anat., Bd. 12.

- 1911 The solenogastres. Mem Mus. Comp. Zool. Harvard Coll., vol. 45, no. 1.

- 1918 The solenogastres from the eastern const of North $\Lambda$ merica. Ditto, vol. 45 , no. 2 .

Huristas, II. 1929 Aplacophora. Flassen und Ordnungen des Tier-Reichs. Bd. 3, Abt. 1, Nachtr. 1.-Polyplacophora. Ditto, Bd. 3, Abt. 1, Nachtr. 2.

Nirkarasz, H. F, 1902 The solenogastres of the Siboga-Expedition.

On!str, N. 1921 Norwegian solenogastres. Bergens Mus. Aarb. 1918.19, no. 3.

Patvit, G. 1890 Sur le développement d'un solénogasire. C. R. Acad. Sci. Paris, tom. 111.

-_.. 1892 Sur l'embryogénie d'une Pronecmenict. Ditto, tom. 111. 


\section{EXPLANATION OF PLATE 1}

Fig. 1a. Young trochophore within egg-capsule, dorsal view (L. 0.f - $0.55 \mathrm{~mm}$ ).

Fig. 1b. The same, ventral view. a. apical flagella, b. cephalic segment, c. prototroch, d. prepedal cavity, e. middle segment, f. caudal segment, g. telotroch, h. foot, i. stomodeal pit.

Fig. 2a. Advanced trochophore in free-swimming life, from dorsal side (L. 075 $0.8 \mathrm{~mm}$ ).

Fig. 2b. The same, from ventral side.

Fig. 3. Young larva - 2 days) immediately after metamorphosis, from side (L. 0.8-0.9 mm). a. stomodeal pit, b. prepedal cavity, c. foot. d. proctodeal invagination.

Fig. 4. Fight-day larva seen from lateral ventral side iL. $2 \mathrm{~mm}$ ).

Fig. 5. Later stage (16-30 days, length of body increasing up to $3 \mathrm{~mm}$, from lateral side. 


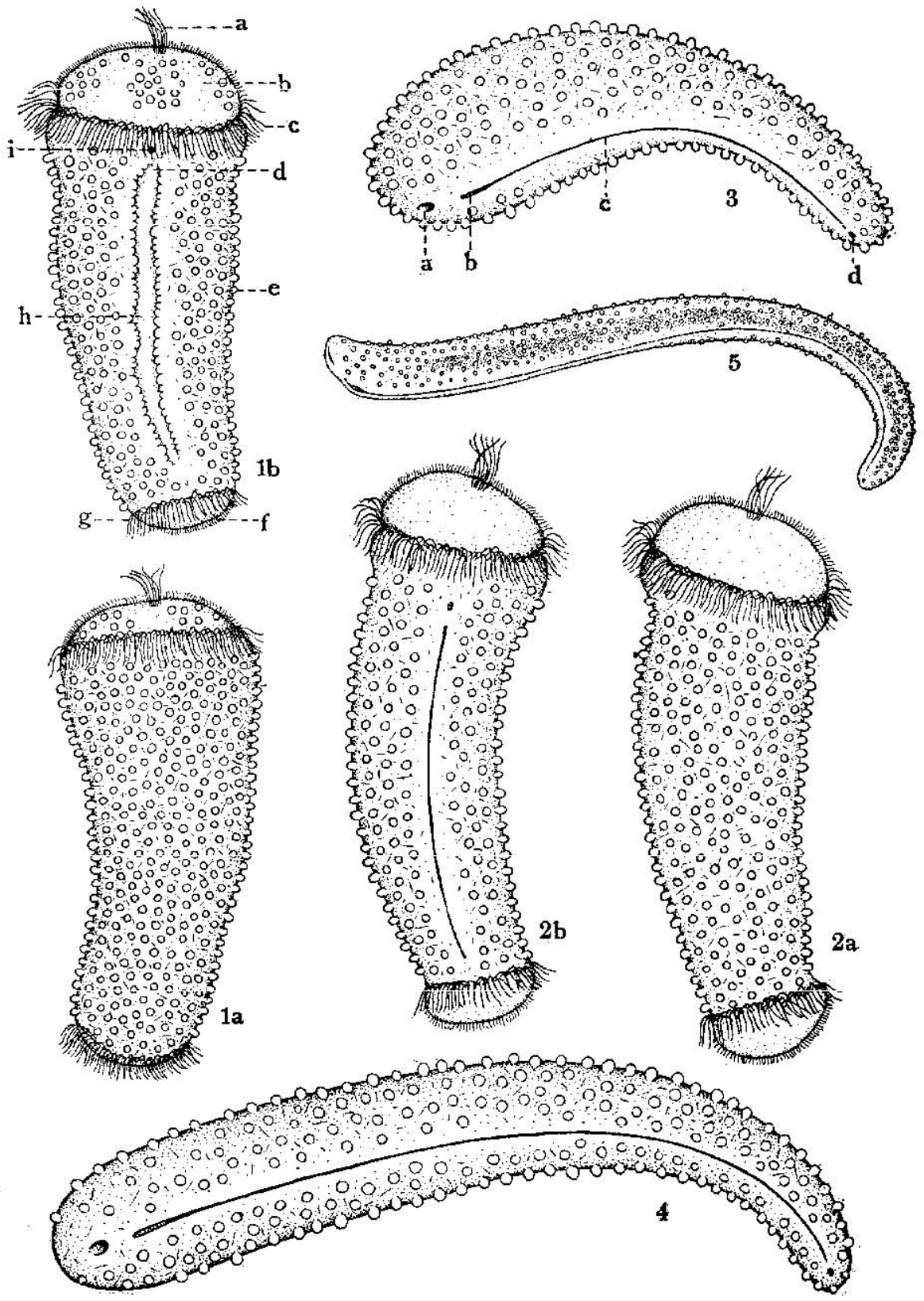

